\title{
С.М. Бичурина
}

Гимназия № 13,

603155 г. Нижний Новгород, Российская Федерация

\section{Методика изучения лирического цикла А.Т. Твардовского «Памяти матери» в 11 классе}

Аннотация. Данная статья является одной из серии работ автора, посвященных изучению лирических циклов на уроках литературы в старших классах. Методика основывается на филологической концепции Э.А. Стерьёпулу, которая адаптируется к школьным условиям. Согласно данной концепции, лирический цикл рассматривается как система поэтических текстов, обладающая такими признаками, как взаимосвязанность, взаимодополнительность, валентность и целостность. Опираясь на перечисленные литературоведческие понятия, автор статьи выстраивает логику работы с циклом на уроке, рассматривает и описывает несколько путей изучения лирического цикла на уроках литературы в школе: 1) линейный, или "вслед за автором», когда стихотворения, входящие в цикл, разбираются последовательно; 2) «концентрический», когда подробно рассматривается одно, как правило, центральное (доминантное) стихотворение, а от него протягиваются смысловые нити к остальным; 3) особый вариант «концентрической» логики, когда на учебном занятии оказывается в центре внимания образ (образы) или мотив (мотивы), скрепляющий стихотворения. В данной статье представлено, как данные модели могут реализовываться в ходе изучения цикла А.Т. Твардовского «Памяти матери». В работе приведена система вопросов и заданий, организующих деятельность учителя и учащихся на уроке, а также развернутые комментарии к ним. Результатом подобных уроков является то, что учащиеся получают возможность подойти к пониманию цикла как целостного образования, обладающего метасмыслом, а это, в свою очередь, способствует развитию не только читательской компетенции, но и системности мышления.

Ключевые слова: изучение лирики А.Т. Твардовского в школе, филологическая концепция Э.А. Стерьёпулу, лирический цикл, художественный мотив, художественный образ, целостность, взаимодополнительность, система поэтических текстов

\section{S.M. Bichurina}

Gymnasium No. 13, Nizhny Novgorod, 603155, Russian Federation

\section{Methodology for studying A.T. Tvardovsky's lyrical cycle "In Mother's Memory" in the 11th grade}

\begin{abstract}
This article is one of a series of the author's works devoted to the study of lyrical cycles in high school lessons in Literature. The described methodology is based on the textual concept worked out by E.A. Sterjopulu that is adapted to the school environment. According to this concept, the lyrical cycle is considered as a system of poetic texts that has a number of features: interrelatedness, inter-complementation, valency and cohesiveness. Based on the listed literary concepts, the author of the article builds the logic of work with the cycle at the lesson, examines
\end{abstract}


and describes several ways of studying the lyrical cycle in literature classes at school: 1) linear, or "following the author", when the writing elements included in the cycle are analyzed sequentially; 2) "concentric", when one, as a rule, the central (dominant) poem is examined in detail, and semantic threads extend from it to the others; 3 ) a special version of the "concentric" logic, when the image (images) or motive (motives) that consolidates the poems is in the focus of attention. This article presents the way these models can be implemented in the course of studying A.T. Tvardovsky's cycle "In Mother's Memory". The paper presents a system of questions and tasks that organize the activities of the teacher and students in the classroom, as well as detailed comments on them. The result of such lessons is that students are able to understand the cycle as a holistic unit that has a meta-meaning. This, in its turn, contributes to the development not only of the competence in reading, but also of the systematic thinking.

Key words: studying the lyric poetry of A.T. Tvardovsky's at school, E.A. Sterjopulu's textual concepts, lyrical cycle, artistic motive, artistic image, cohesiveness, inter-complementation, system of poetic texts 